\title{
PERSEPSI DAN ASPIRASI PENDIDIKAN \\ MASYARAKAT DESA JUMBA
}

\section{Ahim Sulthan Nuruddaroini, Nor Hayati B, Nor Hidayah, Elita Khafijah, Muslimatul Jannah}

Sekolah Tinggi Ilmu al-Qur'an (STIQ) Amuntai

\begin{abstract}
Abstrak
Di era globalisasi pendidikan di berbagai belahan dunia mengalami perubahan sangat mendasar. Ada banyak kemajuan ilmu pengetabuan dan teknologi yang bisa dinikmati umat manusia. Namun sebaliknya, kemajuan tersebut juga beriringan dengan kesengsaraan banyak anak manusia dan kerusakan moral apalagi dalam era globalisasi sekarang ini. Penelitian bertujuan untuk mendeskripsikan tentang persepsi dan aspirasi masyarakat Desa Jumba tentang pendidikan. Penelitian ini menggunakan metode kualitatif dengan jenis deskriptif. Teknik pengumpulan data menggunakan observasi, wawancara dan dokumentasi. Sedangkan teknik analisis data menggunakan teknik reduksi data, display data dan verifikasi data. Hasil penelitian ini adalah terdapat persepsi dan aspirasi pendidikan masyarakat Desa Jumba yaitu: Pendidikan era globlasasi dan sebelum era globalisasi terdapat perbedaan, baik dari segi akhlak, materi, sarana dan prasarana. Selain itu pendidikan di masa pandemic covid-19 juga menyulitkean bagi orang tua. Adapun aspirasi masyarakat Desa Jumba, pendidikan lebih diperhatikan lagi oleh pemerintah, agar tujuan pendidikan yang sebenarnya benar-benar tercapai dan terwujud. Penelitian ini secara empiris, teoretis dan praktis dapat memberikan kontribusi sebagai bahan pertimbangan bagi pemerintah dan bagi setiap yang berkecimpung dalam dunia pendidikan, untuk lebih memperhatikan kebutuhan masyarakat untuk menghadapi tantangan globalisasi.
\end{abstract}

Kata Kunci: Persepsi dan Aspirasi, Pendidikan, Desa Jumba 


\section{PENDAHULUAN}

Era globalisasi telah menjadi sebuah realitas yang harus dihadapi oleh masyarakat dan bangsa Indonesia. Perubahan yang berlangsung begitu cepat dan munculnya berbagai tantangan sebagai dampak globalisasi harus dihadapi dan diselesaikan baik pada tingkat wacana maupun kebijakan aksi. Pendidikan mau tidak mau terlibat di dalamnya dan dituntut untuk mampu memberikan kontribusi yang signifikan ${ }^{1}$.

Globalisasi telah menjadi kekuatan besar yang membutuhkan respon tepat karena ia memaksa suatu strategi bertahan hidup (survival strategy) dan strategi pengumpulan kekayaan (accumulative strategy) bagi berbagai kelompok dan masyarakat. proses ini telah membawa "pasar" menjadi kekuatan dominan dalam pembentukan nilai dan tatanan sosial yang bertumpu pada prinsip-prinsip komunikasi padat dan canggih. Pasar telah pula memperluas orientasi masyarakat dan mobilitas batas-batas sosial budaya. Pasar sekaligus mengaburkan batas-batas itu akibat berubahnya orientasi ruang dalam masyarakat $^{2}$

Strategi yang utama untuk membangun bangsa bermartabat adalah melalui pendidikan. Untuk mencapai hal itu, diperlukan pembentukan pandangan hidup yang masyarakat yang dapat mengarahkannya menjadi bangsa yang bermartabat. Selain itu, lembaga pendidikan juga merupakan proses pembentukan manusia yang cerdas, bermoral, memiliki motivasi hidup dan semangat mengembangkan ilmu dan teknologi 3

Di era globalisasi ini, dunia pendidikan pada umumnya sedang menghadapi berbagai tantangan, antara lain: Pertama, globalisasi di bidang budaya, etika dan moral sebagai akibat dari kemajuan teknologi di bidang transportasi dan informasi. Kedua,

\footnotetext{
1 Rusniati Rusniati, "Pendidikan Nasional Dan Tantangan Globalisasi: Kajian Kritis Terhadap Pemikiran A. Malik Fajar,” JURNAL ILMLAH DID AKTIKA: Media Ilmiah Pendidikan dan Pengajaran 16, no. 1 (2015): 105-28.

${ }^{2}$ Irawan Abdullah, Kontruksi dan Reproduksi Kebudayaan (Yogyakarta: Pustaka Pelajar, 2010).

${ }^{3}$ Hasbi Indra, Pendidikan Islam Melawan Globalisasi (Jakarta: Ridamulia, 2005), 189.
} 
diberlakukannya globalisasi dan perdagangan bebas, yang berarti persaingan alumni dalam pekerjaan semakin ketat. Ketiga, hasil-hasil survey internasional menunjukkan bahwa mutu pendidikan di Indonesia masih rendah atau bahkan selalu ditempatkan dalam posisi juru kunci jika dibandingkan dengan negara-negara tetangga. Keempat, masalah rendahnya tingkat social-capita. Inti dari social capital adalah trust sikap amanah $^{4}$.

Teknologi merupakan hasil dari perkembangan ilmu pengetahuan, yang terjadi di dunia pendidikan. Oleh karena itu, sudah selayaknya pendidikan sendiri juga memanfaatkan teknologi untuk membantu pelaksanaan pembelajaran. Hal ini sesuai dengan pendapat Tondeur ${ }^{5}$ yang menyatakan bahwa teknologi digital kini sudah mulai digunakan di dalam lembaga pendidikan sebagai sarana untuk mendukung pembelajaran, baik sebagai alat informasi (yaitu sebagai sarana mengakses informasi) atau sebagai alat pembelajaran (yaitu sebagai sarana penunjang kegiatan belajar dan tugas).

Ilmu pengetahuan semakin berkembang dari masa ke masa. Perkembangan ilmu pengetahuan ini mendukung untuk terciptanya teknologi-teknologi baru yang menandai adanya kemajuan zaman. Hingga kini, teknologi yang berkembang sudah memasuki tahap digital. Termasuk di Indonesia, setiap bidang sudah mulai memanfaatkan teknologi untuk memudahkan pekerjaan, termasuk juga di bidang pendidikan.

Sebagai suatu entitas yang terkait dalam budaya dan peradaban manusia, pendidikan di berbagai belahan dunia mengalami perubahan sangat mendasar dalam era globalisasi. Ada banyak kemajuan ilmu pengetahuan dan teknologi yang bisa dinikmati umat manusia. Namun sebaliknya, kemajuan tersebut juga beriringan dengan

\footnotetext{
${ }^{4}$ Rusniati, "Pendidikan Nasional Dan Tantangan Globalisasi: Kajian Kritis Terhadap Pemikiran A. Malik Fajar."

5 "Education and Technology. Key Issues and Debates. London: Continuum Int. Publ," Group, 2011.
} 
kesengsaraan banyak anak manusia dan kerusakan moral apalagi dalam era globalisasi sekarang ini.

Sebagaimana yang diungkapkan oleh masyarakat Desa Jumba, bahwa pendidikan di era sekarang (era globalisasi) mengalami penurunan moral, akhlak dan sopan santun pada anak. Menurutnya hal ini sangat berbeda dengan pendidikan di era sebelum meledaknya teknologi seperti sekarang ini. Memang benar sekarang semua serba mudah, serba instan dan mudah dijangkau terutama pendidikan. Sarana dan prasarana yang serba canggih, sehingga memudahkan bagi dunia pendidikan khusunya. Namun, hal tersebut banyak memiliki dampak negative terutama pada pendidikan akhlak anak. Menurut masyarakat Desa Jumba pendidikan sekarang perlu adanya perbaikan dan perubahan terutama kurikulum yang lebih mengedapankan pendidikan akhlak, moral, dan sopan santun.

Selain itu, dimasa pandemic covid-19 ini orang tua merasa sulit dan kewalahan dengan adanya pembelajaran system daring, yang mana materi-materi yang berbeda dengan materi pada masa mereka dulu, ditambah lagi orang tua sibuk bekerja, tidak bisa teknologi, tidak mampu mengontrol anak-anak mereka dalam hal penggunaan teknologi, sehingga anak-anak mereka tidak mempergunakan teknologi dengan semsetinya, dan pada akhirnya akan merusak moral pada anak. Mereka berharap agar pemerintah lebih memperhatikan hal tersebut.

Penelitian ini berangkat dari fenomena dan problem-problem yang sedang terjadi di era globalisasi ini menurut pandangan masyarakat Desa Jumba. Oleh karena itu penelitian ini akan membahas secara komprehensif dan kredibel dengan menuliskannya dengan judul "Persepsi Dan Aspirasi Pendidikan Masyarakat Desa Jumba"

\section{METODE PENELITIAN}

Pendekatan yang peneliti gunakan dalam penelitian ini adalah penelitian kualitatif. Jenis penelitian yang digunakan dalam penelitian ini adalah deskriptif. Penelitian ini 
dilakukan di Desa Jumba Kec. Amuntai Selatan Kab. Hulu Sungai Utara yang mana difokuskan pada cara pandang masyarakat setempat terhadap persepsi dan aspirasi atas pendidikan. Teknik pengumpulan data dalam penelitian kualitatif berjalan dari medan empiris dalam membangun teori dan data ${ }^{6}$. Prosedur penelitian data ini meliputi: getting in, getting a long, pengumpulan data (dengan teknik observasi, wawancara, dan dokumentasi). Penelitian ini menggunakan teknik analisis deskriptif kualitatif maka dalam analisis data ini, penulis menyajikan data berupa kata-kata yang penulis peroleh ketika kegiatan wawancara dan beberapa dokumen yang berkaitan dengan judul, setelah itu penulis berusaha menggabungkannya dan menyesuaikannya dengan teori-teori yang penulis dapatkan ${ }^{7}$.

\section{HASIL DAN PEMBAHASAN}

\section{Persepsi Dan Aspirasi Pendidikan Masyarakat Jumba}

Desa Jumba merupakan sebuah desa yang terletak di Kecamatan Amuntai Selatan, Kabupaten Hulu Sungai Utara, Provinsi Kalimantan Selatan, Indonesia. Berdasarkan hasil wawancara dan observasi yang penulis lakukan, dapat diperoleh data yang menunjukkan bahwa masyarakat Desa Jumba memiliki persepsi dan aspirasi tentang pendidikan, baik pendidikan di era sebelum merebaknya teknologi maupun pendidikan masa sekarang yaitu masa yang bisa disebut dengan istilah pendidikan di era globalisasi. Selain itu juga terdapat persepsi dan aspirasi masyarakat Desa Jumba tentang pendidikan di masa pandemic covid-19. Adapun penyajian data dan analisis data dari hasil observasi dan wawancara pada masyarakat Desa Jumba, Amuntai Selatan dapat diuraikan sebagai berikut:

\footnotetext{
${ }^{6}$ Lexy j. Moleong, Metode Penelitian Kualitatif (Bandung: Remaja Rosdakarya, 2016).

${ }^{7}$ Suharsimi Arikunto, Prosedur Penelitian (Suatu Pendekatan Praktek) (Jakarta: Rineka Cipta, 2002).
} 


\section{Persepi Pendidikan Masyarakat Desa Jumba}

\section{Dari segi Akhlak}

Akhlak berasal dari bahasa Arab jama' dari bentuk mufradatnya "khuluqun” yang berarti budi pekerti, perangai, tingkah laku dan tabiat. Sedangkan menurut istilah adalah pengetahuan yang menjelaskan tentang baik dan buruk (benar dan salah), mengatur pergaulan manusia, dan menentukan tujuan akhir dari usaha dan pekerjaannya. Akhlak pada dasarnya melekat dalam diri seseorang, bersatu dengan perilaku atau perbuatan. Jika perilaku yang melekat itu buruk, maka disebut akhlak yang buruk atau akhlak mazmumah. Sebaliknya, apabila perilaku tersebut baik disebut akhlak mahmudah ${ }^{8}$. Berdasarkan hasil wawancara dengan masyarakat Desa Jumba bahwa pendidikan di era sebelum adanya kemajuan teknologi (sebelum era globalisasi), pendidikan lebih mengutakan pendidikan agama. Seperti halnya mengutakan pendidikan aqidah akhlak; tata krama, adab dan sopan santun yang ditanamkan pada setiap pribadi anak sejak usia dini, dengan mengamalkannya di kehidupan sehari-hari, sehingga ilmu tersebut lebih melekat dan membekas dan menjadi pribadi yang berkarakter.

Sebagai bukti bahwa pendidikan dahulu, sebelum berkembangnya teknologi itu lebih baik dan berhasil. Menurutnya hal ini bisa dibuktikan dengan moral dan karakter anak-anak zaman sekarang sangatlah berbeda dengan anakanak zaman dulu. Kalau anak dulu di kehidupan sehari-harinya memang benarbenar mengamalkan apa yang telah pelajari, seperti mengaplikasikan akhlak yang baik di kehidupan sehari-harinya. Sebagai contoh, ketika anak berhadapan dengan gurunya, mereka benar-benar menghormati dan memuliakan gurunya,

\footnotetext{
${ }^{8}$ Syarifah Habibah, “Akhlak dan Etika Dalam Islam,” Jurnal Pesona Dasar 1, no. 4 (2015): 73.
} 
sampai-sampai melihat gurunya saja tidak berani, karena khawatir ilmu yang telah diberikan oleh gurunya tidak bermanfaat.

Tidak hanya kepada guru yang mengajarkan ilmu, namun kepada kedua orang tua juga demikian. Menurutnya mengapa anak begitu kental dengan akhlak yang baik dikehidupan sehari-harinya, hal ini karena apa yang telah disampaikan oleh gurunya, mereka benar-benar mengamalkannya, terutama bagaimana etika kepada guru dan orang tua. Sebagai contoh, ketika orang tua memanggil anakanaknya hanya cukup dengan satu kali panggilan, mereka dengan cepat dan tanggap untuk memenuhi panggilan orang tuanya. Selain itu, ketika orang tua memberikan nasihat kepada anak-anaknya, mereka diam dan mendengarkan apa yang disampaikan oleh orangtuanya. Bahkan mereka tidak berani menatap maupun menjawab, yang mereka lakukan adalah menjalankan apa yang telah diperintahkan oleh kedua orangtuanya dengan rasa hormat dan tetap menjaga akhlak kepada orangtuanya.

Pada satu sisi, perkembangan dunia IPTEK yang demikian mengagumkan itu memang telah membawa manfaat yang luar biasa bagi kemajuan peradaban umat manusia. Jenis-jenis pekerjaan yang sebelumnya menuntut kemampuan fisik yang cukup besar, kini relatif sudah bisa digantikan oleh perangkat mesin-mesin otomatis. Demikian juga ditemukannya formulasiformulasi baru kapasitas komputer, seolah sudah mampu menggeser posisi kemampuan otak manusia dalam berbagai bidang ilmu dan aktivitas manusia. Ringkas kata kemajuan teknologi saat ini benar-benar telah diakui dan dirasakan memberikan banyak kemudahan dan kenya-manan bagi kehidupan umat manusia ${ }^{9}$.

Di sisi lain, manusia tidak bisa menipu diri sendiri akan kenyataan bahwa teknologi mendatangkan malapetaka dan kesengsaraan bagi manusia modern.

\footnotetext{
${ }^{9}$ Siti Irene Astuti Dwiningrum, Ilmu Sosial \& Budaya Dasar (Yogyakarta: UNY Press, 2012), 171.
} 
Kemajuan teknologi, yang semula untuk memudahkan manusia, ketika urusan itu semakin mudah, maka mun-cul "kesepian" dan keterasingan baru, yakni lunturnya rasa solidaritas, kebersamaan, dan silaturrahmi. Contohnya penemuan televisi, komputer, internet, dan handphone telah me-ngakibatkan kita terlena dengan dunia layar. Layar kemudian menjadi teman setia, bahkan kita lebih memperhatikan dunia layar diban-dingkan istri/suami, dan anak sekalipun. Hampir setiap bangun tidur kita menekan tombol televisi untuk melihat layar, pergi ke kantor tekan tombol handphone melihat layar untuk ber-sms, BBM (Blackberry Messenger) ria atau main game, sampai di kantor sudah tersedia layar komputer atau layar televisi. Begitu juga ketika pulang dari kantor sampai rumah, layar televisi yang dilihat terlebih dahulu bukan istri dan anak. SMS dan BBM membuat manusia mengalami "amnesia" (lupa anak dan istri atau suami). Akibatnya hubungan antar anggota keluarga renggang, satu sama lain asyik dengan layarnya masing-masing. Hal ini baru dalam rumah tangga sendiri, apalagi dengan tetangga, mungkin bertemu tetangga hanya ketika bendera putih (tanda kematian) berdiri di depan rumah tetangga. Ketika itu, baru kita sadar ada anggota tetangga yang wafat. Dengan sedikit basa-basi kita membesuk sebentar sebelum pergi ke kantor ${ }^{1}$.

Selain itu, menurut Taopan dkk, dampak kemajuan teknologi juga mempenharuhi perilaku moral anak-anak. Seperti mengganggu perkembangan anak, mengakibatkan pemborosan, penyalahgunaan fitur-fitur internet (pornografi), menurunkan mental belajar anak ${ }^{1}$. Namun, hal tersebut bisa dicegah dengan adanya upaya-upaya yang mampu membuat anak terhindar dari

\footnotetext{
1 Amsal Bachtiar, Filsafat Ilmu, Revisi (Jakarta: Raja Grafindo Persada, 2012), 223.

1 Yana F Taopan, Mintje Ratoe Oedjjoe, dan Andy Nabu Sogen, "Dampak Perkembangan Teknologi Informasi dan Komunikasi Terhadap Perilaku Moral Remaja di SMA Negeri 3 Kota Kupang," Jurnal Kependidikan: Jurnal Hasil Penelitian dan Kajian Kepustakaan di Bidang Pendidikan, Pengajaran dan Pembelajaran 5, no. 1 (2019): 66.
} 
hal-hal tersebut. Berdasarkan hasil penelitian Ia mengatakan bahwa upaya pihak sekolah yang dianggap paling ideal dalam mengatasi perilaku negatif siswa akibat penggunaan HP maupun informasi negatif yang diakses dari internet, maka kepala sekolah dan semua guru yang diwawancarai berpendapat bahwa cara yang paling efektif adalah: 1) Membekali siswa dengan ilmu agama dan hal tersebut telah mereka lakukan, setiap hari jumat diadakan kebaktian bersama siswa dan guru di sekolah. 2) Razia handphone oleh pihak sekolah. hal tersebut diyakini pihak sekolah dapat memberikan efek jera bagi siswa untuk menyimpan gambar atau video porno di ponsel. Dan untuk memantau aktifitas siswa di luar kelas atau pada saat jam istirahat maka phak sekolah memberikan tanggung jawab kepada setiap anggota osis. Langkah itu terbukti sangat. 3) Adanya kerja sama yang baik antara guru dan orang tua, berupa saling memberikan informasi tentang perkembangan perilaku, dan kemampuan belajar siswa di rumah maupun di sekolah, seperti pernyataan dari ibu kepala sekolah SMA N 3 Kupang Dra Selfina Dethan ${ }^{1}$.

Pendidikan di era globalisasi jika dilihat dari aspek pendidikan agama Islam telah mengalami pergeseran inti dari tujuan pendidikan itu sendiri, menurut persepsi masyarakat Desa Jumba lebih mementingkan dunia (pendidikan sebagai ajang investasi dunia semata). Hal ini berdasarkan hasil wawancara dengan masyarakat Desa Jumba bahwa pendidikan sekarang kebanyakan hanya di jadikan sebagai investasi, hanya di tujukan untuk tujuan ekonomi semata, seperti kalau sekolah disini besarnya nanti seperti ini, bisa kerja dengan gaji tinggi. Berbeda dengan dulu, kami menuntut ilmu dengan niat yang lurus dan juga pendidikan kami lebih mengutamakan akhlak, adab dan moral. Sangat berbeda dengan sekarang pendidikan dijadikan sebagai investasi ekonomi. Pendidikan sekarang ini seperti telah disalah gunakan.

\footnotetext{
1 Taopan, Oedjoe, dan Sogen, 72. ${ }^{2}$
} 
Era globalisasi telah menjadi sebuah realitas yang harus dihadapi oleh masyarakat dan bangsa Indonesia. Perubahan yang berlangsung begitu cepat dan munculnya berbagai tantangan sebagai dampak globalisasi harus dihdapi dan diselesaikan baik pada tangkat wacana maupun kebijakan aksi ${ }^{1}$. Di era globalisasi ini, dunia pendidikan pada umumnya sedang menghadapi berbagai tantangan, antara lain: Pertama, globalisasi di bidang budaya, etika dan moral sebagai akibat dari kemajuan teknologi di bidang transportasi dan informasi. Kedua, diberlakukannya globalisasi dan perdagangan bebas, yang berarti persaingan alumni dalam pekerjaan semakin ketat. Ketiga, hasil-hasil survey internasional menunjukkan bahwa mutu pendidikan di Indonesia masih rendah atau bahkan selalu ditempatkan dalam posisi juru kunci jika dibandingkan dengan negara-negara tetangga. Keempat, masalah rendahnya tingkat socialcapita. Inti dari social capital adalah trust sikap amanah ${ }^{1}$.

Strategi yang utama untuk membangun bangsa bermartabat adalah melalui pendidikan ${ }^{1}$. Sesuai dengan UU No. 20 tahun 2003 tentang Sistem Pendidikan Nasional, Pasal 3, Tujuan pendidikan Nasional adalah "Mengembangkan potensi Peserta didik agar menjadi manusia yang beriman dan bertakwa kepada Tuhan Yang Maha Esa, berakhlak mulia, sehat, berilmu, cakap kreatif, mandiri dan menjadi warga negara yang demokratis serta bertanggung jawab.” Pendidikan yang memanusiakan manusia adalah sebuah keharusan karena ia menjadi pilar dasar bagi keberhasilan pendidikan sebagai bagian yang penting untuk mencerdaskan kehidupan bangsa. M. Sastrapratedja menawarkan pendidikan berwawasan kemanu siaan itu ada tiga kekuatan dalam

\footnotetext{
1 Muhammad Said dan Juminar AfPan, Mendidik dari Zaman Ke Zaman (Jakarta: Kalam Mulia, 1987), 45.

1 Rusniati, "Pendidikan Nasional Đan Tantangan Globalisasi: Kajian Kritis Terhadap Pemikiran A. Malik Fajar," 109.

1 Eva Dewi, "Potret Pendidikan di Êra Globalisasi Teknosentrisme dan Proses Dehumanisasi," Sukma: Jurnal Pendidikan 3, no. 1 (2019): 95.
} 
diri peserta didik yang harus ditumbuhkan: (1) daya untuk berbuat (power to); (2) solidaritas dan kekuatan bersama untuk memecahkan permasalahan yang dihadapi dan untuk kesejahteraan bersama (power with); dan (3) kekuatan spritual dan nilai-nilai yang ada dalam diri anak agar lebih manusiawi (bermartabat) (power within) ${ }^{1}$. 6

Realitasnya, pendidikan dewasa ini mengalami krisis nilai. Pendidikan hanya menghasilkan output-output atau lulusan yang pintar secara kognitif, banyak menguasai teori dan teknologi, tetapi kering dari nilai-nilai kemanusiaan dan sosial dalam penerapannya. Pertanyaan yang sering muncul adalah bagaimana anak bisa mencapai nilai yang tinggi, artinya keberhasilan seorang anak hanya diukur dengan angka atau nilai raport, menguasai teknologi, cepat mencapai gelar Sarjana, Master, Doktor atau Profesor, setelah lulus dari instansi pendidikan akan kerja di mana, dan sebagainya. Nilai-nilai humanistik, jujur, disiplin, tanggung jawab terabaikan dan kurang mendapat perhatian utama baik dari lembaga pendidikan maupun masyarakat ${ }^{1}$. Hal ini akan berefek pada memperburuk kualitas Sumber Daya Manusia (SDM) dan kepemimpinan masa depan. Hal ini didorong oleh sifat dan tujuan manusia untuk mengumpulkan atau mengakumulasikan kapital sebanyak-banyaknya. Lembaga Pendidikan kehilangan budaya akademik menjadi budaya ekonomis. Lembaga pendidikan lebih mengutamakan menerima calon siswa yang lebih kaya walaupun IQ nya pas-pasan, dan siswa yang memiliki IQ yang tinggi terpinggirkan karena miskin dan tidak memiliki uang yang cukup untuk melanjutkan pendidikan lebih tinggi. Para guru dan calon sarjana memiliki mental pedagang ketimbang mental pendidik dan profesional. Hal ini tentu saja mereduksi fungsi pendidikan sebagai

1 Moh Yamin, Menggugat Pendidikan Indonesia (Yogyakarta: Ar-Ruzz Media, 2009), 222.

1 Dewi, "Potret Pendidikan di Era ${ }^{\top}$ Globalisasi Teknosentrisme dan Proses Dehumanisasi," 96.

23 
pemberdayaan kemajuan dan mencerdaskan kehidupan bangsa bergeser pada privatisasi pendidikan pada pelanggengan poverty trap. (jebakan kemiskinan) ${ }^{1}$.

Menurut Dewi melihat dampak globalisasi terhadap proses pendidikan saat ini, maka perlu reorientasi pendidikan ke depan sebagai tombak kemajuan mencerdaskan kehidupan bangsa. Globalisasi bukanlah suatu hal yang dijauhi, akan tetapi perlu diikuti dengan kesiapan mental dan daya nalar yang kritis, humanis dan agamis, sehingga pendidikan mampu melahirkan output-output yang cerdas secara intelektual, personal, sosial dan kinestesis vokasional ${ }^{1}$.

\section{Dari Segi Materi}

Materi sekarang lebih nyaman dari yang dulu karena banyak saranasarana yang dipakai. Dulu guru sangat susah mengajari anak-anak karena saranasarana yang ada pun tidak sebagus zaman sekarang, yang mana sekarang guru nyaman mengajari anak-anak juga nyaman belajar, karena banyak sarana yang membantu dan memudahkan proses pembelajaran. Hanya saja murid sekarang menjadi banyak yang malas. Banyak perbedaan pendidikan dahulu dan sekarang walaupun dahulu pelajaran sulit namun bagus. Sekarang pendidikan sudah nyaman dan mudah, akan tetapi seperti kurang. Menurutnya karena pendidikan sekarang dijadikan sebagai investasi atau sebagai jalan untuk mencari pekerjaan atau uang nantinya. Kalau dulu waktu saya sekolah yang seperti itu ada tapi kami lebih mengutamakan moral dan adab agar manusia lebih baik dan berakhlak karena itu yang paling penting.

Selain itu, menurut masyarakat Desa Jumba, materi pendidikan zaman sekarang terdapat perbedaan. Kalau materi zaman dulu tidak terlalu banyak

1 Imam Machali, Pendidikan Islam dian Tantangan Globalisasi (Yogyakarta: PRESMA Fak. Tarbiyah UIN Sunan Kalijaga, 2004), 127-28.

1 Dewi, "Potret Pendidikan di Era QGlobalisasi Teknosentrisme dan Proses Dehumanisasi," 109. 
seperti sekarang. Mater-materi zaman dulu lebih menekankan pada materimateri keagamaan seperti materi akidah, akhlak, moral dan langsung dipraktikkan di kehidupan sehari-hari. Hal ini berbeda dengan zaman sekarang, menurutnya materi zaman sekarang lebih banyak dan membuat anak bingung. Tidak hanya anak-anak mereka yang mengalami kebingungan, namun hal ini akan berimbas kepada orang tua yang berbeda dengan pendidikan pada masanya.

Perbedaan yang mendasar adalah pendidikan dulu sangat kental dan lebih mengedapan kan ilmu agama, hal ni bisa dilihat bahwa pada zaman dulu, materi-materi yang dipelajari seputar bidang akidah dan akhlak yang lebih diutamakan. Seperti materi tentang akidah dan akhlak sifat dua puluh, ta'lim mutaallim yang menekankan pada adab dan sopan santun. Setelah materi disampaikan, guru terlebih dahulu memberikan contoh terkait adab-adab tersebut, sehingga anak atau siswa lebih cepat mengamalkan ilmu-ilmu yang telah disampaikan oleh gurunya. Selain itu, guru zaman dulu memang tegas dan keras, namun hal itu adalah hal yang sangat baik. Karena dengan begitu anak menjadi segan, hormat dan sopan terhadap guru maupun orang tua.

Sebagaimana yang diungkapkan oleh salah satu masyarakat Desa Jumba, Ia mengatakan bahwa Ia ketika sekolah dulu, guru-guru dulu itu mereka tegas, kejam-kejam tapi itu yang dirindukan sekali, karena akibat ketegasan guru kita tahu disiplin, kita juga punya rasa takut terhadap guru jadi ilmu yang diajarkan melekat. Entah bagaimana guru sekarang saya tidak tahu, tapi ada satu hal yang membuat saya bertanya-tanya terhadap guru-guru sekarang ini. dirumah kalo saya menegur anak-anak mereka sering gak nurut tapi kalo dengan guru mereka patuh sekali. 
Menurut Djamaluddin dan Abdullah Aly ${ }^{2}$, bahwa pendidikan Islam adalah bimbingan yang dilakukan oleh seorang dewasa kepada terdidik dalam masa pertumbuhan agar ia memiliki kepribadian muslim. Sistem pendidikan Islam adalah keseluruhan komponen pendidikan Islam yang saling terkait secara terpadu untuk mencapai tujuan pendidikan Islam. "Komponen-komponen atau faktor pendukung pendidikan meliputi: peserta didik, pendidik, instrumen pembelajaran, instrumen penunjang, dan penggerak proses pendidikan. Tujuan pendidikan agama menurut Moh. Roqib ${ }^{2}$ adalah mempersiapkan individu agar hidup sempurna. belajar etika dunia agar dapat eksis di dunia dan belajar etika agama agar dapat berkomunikasi dengan Allah swt di setiap tempat, takut kepada-Nya di saat sirri atau terang (sendirian atau bersama orang lain), kuat fisik, berpikir sistematis, tahu cara menolong orang lain, dan melakukan kewajiban ritual dan sosial yang lain.

Pendidikan Islam dewasa ini, dari segi apa saja terlihat goyah terutama karena orientasi yang semakin tidak jelas, ${ }^{2}$ semestinya "sistem pend̊dikan Islam haruslah senantiasa mengorientasi diri kepada menjawab kebutuhan dan tantangan yang muncul dalam masyarakat kita sebagai konsekuensi logis dari perubahan, ${ }^{2}$ jika tidak, maka pendidîkan Islam di Indonesia akan mengalami ketinggalan dalam persaingan global.

Orientasi pendidikan Islam di Indonesia masih mengalami perbedaan pendapat, terutama dalam menentukan pola, arah, dan capaian tertentu yang diinginkan, sehingga pendidikan Islam belum mendapat pengakuan secara internasional dalam era global ini maka seyogyanya orientasi pendidikan Islam

\footnotetext{
2 Kapita Selekta Pendidikan Islam (Bahdung: CV Pustaka Setia, 1999), 10.

2 Pendidikan Perempuan (Yogyakarta: Gema Media dengan STAIN Press, 2003), 82.

2 Muslim Usa, Pendidikan Islam di Ihdonesia antara Cita dan Fakta (Yogyakarta: Tiara Wacana, 1991), 11.

2 Azyumardi Azra, Pendidikan Islam ${ }^{3}$ Tradisi dan Modernisasi Menuju Melenium Baru, Logo (Jakarta: Macana Ilmu, 1999), 57.
} 
bukan hanya dengan model-model pendidikan dan pembelajaran seperti yang sudah ada sekarang ini, yang seharusnya terus menerus melakukan reformasi (pembaruan) dan inovasi serta kerja keras untuk memperbaiki kelemahan dan kekurangan menuju langkah baru ke arah kemajuan dan perkembangan sesuai dengan tuntutan zaman sehingga pemerataan, mutu, relevansi, dan efektif dan efisiensi dari pendidikan dapat diselesaikan dengan baik dan benar, hal itu karena tuntutan globalisasi bukan lagi hanya sampai tingkat mengenyam pendidikan akan tetapi keperluan akan keterampilan yang bisa menjadi nilai jual bagi diri, masyarakat dan negaranya. Selain itu juga perlu usaha penelaahan kembali atas aspek-aspek sistem pendidikan yang berorientasi pada rumusan tujuan yang baru 2 .

Lembaga pendidikan Islam sekarang lebih pada orientasi yang bersifat transfer of knowledge and skill dalam mengembangkan proses intelektualisasi dan kurang memperhatikan dalam pembinaan "qalbun salim" dengan berupaya terwujudnya generasi yang memiliki "bastatan fil-ilmi wal jism” yang diliputi oleh spritualisasi dm disiplin moral yang islami. Pada akhirnya wawasan pendidikan agama menjadi terbelah ${ }^{2}$. 5

Menurut Dacholfany, Setiap kegiatan pendidikan agama Islam seharusnya diorientasikan pada pencapaian kompetensi yang berhubungan dengan pengembangan kecerdasan emosional, sosial, intelektual, intelligence, terlebih lagi pada aspek spiritual maka dalam mencapai tujuan yang diharapkan maka diperlukan media yang relevan di antaranya yang berupa kurikulum ${ }^{2}$.

Menurut Dedi Mulyasa, kurikulum dapat diartikan sebagai seperangkat rencana dan pengaturan mengenai tujuan, kompetensi dasar, materi standar dan

2 Jusuf Amir Faisal, Reorientasi Pendtdikan Islam (Jakarta: Gema Insani Press, 1995), 23.

2 M Ihsan Dacholfany, "Reformasi Pendidikan Islam Dalam Menghadapi Era Globalisasi," AKADEMIKA: Jurnal Pemikiran Islam 20, no. 1 (2015): 179-80.

2 Dacholfany, 182. 
hasil belajara serta yang digunakan sebagai pedoman penyelenggaraan kegiatan pembelajaran untuk mencapai kompetensi dasar dan tujuan pendidikan. Kurikulum adalah suatu program pendidikan yang direncanakan, di programkan, dan dirancang sedemikian rupa secara sistematis yang berisi bahan ajar serta pengalaman belajar sehingga dalam program pendidikan memiliki arah dan tujuan yang akan di capai dan dari hasil yang dicapai kita dapat merevisi ulang dan mengembangkan program pendidikan untuk memperoleh hasil yang lebih baik dari sebelumnya sehingga suatu kurikulum pembelajaran dapat dikatakan selalu berubah-ubah sesuai dengan kebutuhan dan perkembangan pendidikan $^{2}$.

Menurut Husain Haikal bahwa dalam bidang pendidikan, hanya sibuk bergulat dengan kurikulum atau mengganti nama sekolah, sementara mutu pendidikan makin merosot. Indonesia seakan-akan berlari di tempat sementara Negari Jiran makin berkembang serta bermutu dunia pendidikannya. Akibatnya, Indonesia makin kekurangan SDM yang bermutu dan kekurangan ini diisi orang asing sehingga mereka berjumlah sekitar 7000 orang dan menyarankan untuk bercermin pada kiprah berbagai Perguruan Tinggi di luar negeri. Namun juga, perlu bercermin pada dinamika Pondok Modern Darussalam Gontor, sebuah ponpes yang terus berkembang walau dimulai dengan pendidikan anak usia dini. Dengan tekad yang kuat dan terus melakukan berbagai terobosan, pondok mampu bertahan dan berkembang. "Salah satu sebabnya barangkali Pondok Modern Darussalam Gontor tidak pernah mengikuti jejak pengelolaan pendidikan Indonesia yang asyik dengan gonta-ganti kurikulum, sementara pihak luar melihatnya sebagai salah satu contoh proyek untuk meraih rupiah. Menariknya, Pondok Modern Darussalam Gontor tetap bertahan dengan kurikulum yang dimilikinya dan tidak tertarik untuk berganti-ganti yang

2 Dedi Mulyasa, Kurikulum Tingkat ${ }^{7}$ Satuan Pendidikan (Bandung: Rosda, 2007), 46. 
melelahkan serta membingungkan semua pihak yang terlibat terutama para guru, siswa, dan orang tua ${ }^{2}$.

Reformasi kurikulum pendidikan agama Islam dalam menghadapi era globalisasi diharapkan adanya perubahan, perbaikan dan penataan kembali secara struktur menjadi lebih baik. Kaitannya dengan kurikulum pendidikan agama Islam, agar dapat direformasi kembali agar kurikulum pendidikan agama Islam sesuai dengan tujuan pendidikan agama Islam sehingga dapat menghadapi berbagai masalah-masalah yang terjadi sekarang ini khusunya dalam menghadapi era globalisasi sehingga dapat memainkan perannya secara dinamis dan proaktif 2

\section{Dari Segi Sarana Dan Prasarana}

Berdasarkan hasil wawancara dengan masyarakat Desa Jumba bahwa untuk masalah pembelajaran nyaman yang sekarang ini, karena banyak bantuan dan juga sarana sarana yang mendukung seperti laptop dan internet, tapi untuk adab dan moral itu kurang, kalau yang dulu pelajarannya sulit kami harus menulis, membaca, menghafal, kalau sekarang kan anak-anak tinggal ambil hp buka google dan sebagainnya.

Menurut wikipedia, kata globalisasi di ambil dari kata global yang maknanya universal. Globalisasi belum memiliki definisi yang mapan kecuali sekitar definisi kerja (working definition), sehingga tergantung dari sisi mana orang melihatnya. Dari perbedaan sudut pandang globalisasi, muncullah masyarakat yang menerima globalisasi (masyarakat pro-globalisasi) dan masyarakat yang menolak globalisasi (masyarakat anti globalisasi). Setiap manusia tidak bisa terhindar dari arus globalisasi ini, kecuali dia tidak menjalin kontak dengan orang lain, tidak melihat acara-acara di televisi, tidak

2 Dacholfany, "Reformasi Pendidikan Islam Dalam Menghadapi Era Globalisasi," 183.

2 Dacholfany, 183. 
mendengarkan radio, dan dia hidup dengan apa adanya. Namun hanya segelintir manusia bisa melakukan hal seperti itu karena manusia memiliki sifat sebagai makhluk sosial yaitu selalu membutuhkan orang lain ${ }^{3}$.

Perkembangan zaman mengakibatkan gaya hidup manusia menjadi berubah yang semula mereka saling membutuhkan menjadi bersikap individualis dan tak peduli dengan orang lain. Globalisasi selain menghadirkan dampak positif untuk hidup mudah, nyaman, murah, indah, maju. juga mendatangkan dampak negatif yaitu menimbulkan keresahan, penderitaan dan penyesatan ${ }^{3}$. Begitujuga dalam hal pendidikan, dengan adanya kemajuan zaman atau disebut dengan era globalisasi yang memberikan banyak kemudahan dan kenyamanan terutama dalam hal sarana dan prasarana pendidikan. Seperti adanya internet, laoptop, hp dll, yang semuanya sangatlah mudah diakses dalam hitungan detik. Namun, hal ini tentunya berakibat terhadap kualitas seseorang, karena semuanya bisa didapatkan dengan mudah dan instan. Berbeda dengan sebelum adanya kemajuan teknologi, manusia berupaya dengan bersusah payah dan sungguhsungguh dalam berbagai hal, meskipun sulit dan berat. Karena minimnya sarana dan prasarana tersebut. Namun, setelah diadakan perbandingan antara pendidikan zaman dulu dan zaman sekarang terdapat perbedaan yang signifikan terutama dalam hal pendidikan akhlak.

Bagi masyarakat, Globalisasi merupakan sebuah fenomena yang banyak menimbulkan dampak negatif yang di bawa oleh negara-negara Barat (terutama Amerika Serikat) dengan tujuan agar masyarakat mengikuti cara hidup di negara mereka. efek-efek negatif tersebut dapat diuraikan sebagai berikut: 1) Pemiskinan nilai spiritual. Tindakan sosial yang mempunyai nilai materi (tidak

3 Amirul Bakhri, "Tantangan Pendilikan Agama Islam di Madrasah pada Era Globalisasi," Madaniyah 5, no. 1 (2015): 65.

3 Bakhri, 66. 
produktif) dianggap sebagai tindakan yang rasional. Jatuhnya manusia dari makhluk spiritual menjadi makhluk material. Peran agama digeser menjadi urusan akhirat sedang urusan dunia menjadi wewenang sains. Tuhan hanya hadir dalam pikiran, lisan, tetapi tidak hadir dalam perilaku dan tindakan. Gabungan ikatan primordial dengan sistem politik melahirkan nepotisme, birokratisme, dan otoriterisme. Individualistik. Terjadinya frustasi eksistensial seperti hasrat yang berlebihan untuk berkuasa merasa hidupnya tidak bermakna. Terjadinya ketegangan-ketegangan informasi di kota dan di desa, kaya dan miskin, konsumeris ${ }^{3}$. Qodri Azizy menyatakañ juga bahwa globalisasi dapat berarti alat. Ketika itu, globalisasi menjadi netral artinya ia mengandung hal-hal positif jika dimanfaatkan dengan tujuan baik dan begitupun sebaliknya. Selain itu globalisasi juga bisa berarti ideologi. Ia sudah mempunyai arti tersendiri dan netralitasnya sangat berkurang menyebabkan terjadi benturan nilai ideologis globalisasi dan nilai agama. Baik sebagai alat atau ideologi, globalisasi menjadi sebagai ancaman sekaligus tantangan ${ }^{3}$.

3

\section{Aspirasi Pendidikan Masyarakat Desa Jumba}

Berdasarkan hasil wawancara dengan masyarakat Desa Jumba, bahwa pendidikan seharusnya lebih mementingkan pendidikan agama dan akhlak. Sebagaimana yang diungkapkan oleh ibu AB, Ia mengatakan bahwa seharusnya pendidikan sekarang lebih menomor satukan pelajaran agama dan akhlak. Karena yang dibutuhkan generasi yang akan datang ini adalah agama ini nomor satu. Menuju generasi yang lebih bermoral, beretika dan ada nilai-nilai kehidupan, tidak seperti anak-anak sekarang ini.

3 Tim Penyusun, Pengantar Studi Islam (Surabaya: IAIN Sunan Ampel Press, 2009), 235.

3 A. Qodri Azizy, Melawan Globalisassi: Interpresi Agama Islam (Yogyakarta: Pustaka Pelajar, 2003), 22. 
Menurut pengalaman beliau, ketika sekolah dulu, guru-guru dulu itu mereka tegas, kejam-kejam tapi itu yang dirindukan sekali, karena akibat ketegasan guru kita tahu disiplin, kita juga punya rasa takut terhadap guru jadi ilmu yang diajarkan melekat. Entah bagaimana guru sekarang saya tidak tahu, tapi ada satu hal yang membuatnya bertanya-tanya terhadap guru-guru sekarang ini. Menurutnya ketika dirumah Ia ketika menegur anak-anak mereka sering tidak menurut, tapi kalau dengan guru mereka patuh sekali. Dimana salahnya ini ? kenapa?, dulu itu setara sama guru patuh sama orang tua lebih patuh lagi seperti itu.

Sekarang ini, menurutnya membingungkan, namun menurut Beliau hal ini merupakan dampak dari perkembangan zaman. Karena sekarang sangat kekurangan materi tentang akhlak, anak-anak hanya tertuju pada nilai pelajaran yang bagus seperti tertancap di otak mereka ini nilai untuk investasi nanti. Beliau masih merasa kebingungan dan bertanya-tanya, salah gurukah atau salah siapa ini? Siapa bisa menjawab?. Anak-anak sekarang mungkin berpikir jika aku patuh dengan guru nilai ku akan bagus kalo sama orang tua tidak ada pengaruh apaapa. Pasti dari guru ini ada tersalah menjelaskan atau menerangkan sesuatu tentang agama yang mana seharusnya anak-anak juga harus patuh kepada orang tua harus tertanam dihati mereka rasa takut dan hormat kepada orang tua, bukan hanya patuh kepada guru. Yang menjadi pertanyaan mendasar adalah mengapa pendidikan sekarang menjadi sepeti ini?

Dari permasalahan tersebut, beliau mengambil kesimupulan bahwa kemungkinan karena zaman sudah berbeda. Intinya materi zaman dulu mengarah ke moralitas, akidah, akhlak, kalau zaman sekarang mengarah ke tujuan invastasi, malah banyak digunakan untuk yang seperti itu ke tujuan ekonomi, besarnya nanti harus jadi ini, dapat ini, hanya mengejar itu semata dan menganggap akhlak belakangan. Harusnya akhlak itu di nomor satukan untuk 
memperbaiki moral untuk kehidupan yang lebih baik dan untuk mengejar investasi dan sebagainya itu nomor 2.

Dalam konteks pendidikan Islam, arus global bisa menimbulkan paradoks atau gejala kontra moralitas, yakni pertentangan dua fisi moral secara diametral ${ }^{3}$. Begitu juga dengan pola kehidupan di barat, tentunya nilai-nilai dan pandangan-pandangan hidup itu sangat erat hubungannya, bahkan sangat mempengaruhi Kerusakan akhlak, moral, adab, akhlak, dan perilaku manusia. Namun di Barat dan Indonesia mengenai nilai-nilai dan pandangan hidup itu tidak sama, maka pancarannya dan pengalamannya dalam bentuk perilaku hidup pun menjadi tidak sama. Dalam ketidaksamaan itu berlangsung pula proses persaingan dan berlomba untuk mempengaruhi pola pikir dan perilaku hidup manusia penghuni bumi ini. Pengaruhnya sangat besar pada kehidupan manusia baik sifatnya jasmaniah maupun rohaniah (fisik, dan mental, materiil dan spiritual) ${ }^{3}$. 5

Reformasi kurikulum pendidikan agama Islam dalam menghadapi era globalisasi diharapkan adanya perubahan, perbaikan dan penataan kembali secara struktur menjadi lebih baik. Kaitannya dengan kurikulum pendidikan agama Islam, agar dapat direformasi kembali agar kurikulum pendidikan agama Islam sesuai dengan tujuan pendidikan agama Islam sehingga dapat menghadapi berbagai masalah-masalah yang terjadi sekarang ini khusunya dalam menghadapi era globalisasi sehingga dapat memainkan perannya secara dinamis dan proaktif 3

Dalam konteks ini pendidikan agama Islam memainkan peranan yang penting di dalam proses globalisasi. Reformasi pendidikan agama Islam bukan

3 Sudarman Danim, Agenda Pembabiaruan Sistem Pendidikan (Yogyakarta: Pustaka Pelajar, 2003), 64.

3 M. Solly Lubis, Umat Islam Dalam ${ }^{5}$ Globalisasi (Jakarta: Gema Insani Press, 1997), 35.

3 Dacholfany, "Reformasi Pendidikan Islam Dalam Menghadapi Era Globalisasi," 183. 
hanya pelengkap tetapi menjadi salah satu komponen penting yang cukup berpengaruh di dalam berbagai proses globalisasi sebab begitu urgenya peran pendidikan agama Islam dalam kehidupan masyarakat, maka perlu kiranya memahami sejauh mana posisi pendidikan agama Islam di dalam merespon berbagai persoalan kemasyarakatan dan negara. Untuk itu, perlu usaha-usaha yang keras menghadapi globalisasi harus dikerjakan oleh pemikir muslim. Reformasi Pendidikan merupakan salah satu bentuk terwujudnya buman capital harus didesain sedemikian rupa sekiranya mampu mencetak sumber daya manusia yang tetap kukuh keimanan dan ketakwaannya, siap berlaga dan sukses di era globalisasi ${ }^{3}$.

7

\section{Persepsi Dan Aspirasi Pendidikan Masyarakat Desa Jumba Di Masa Pandemic Covid-19}

Berdasarkan hasil wawancara dengan Ibu MH, Ia mengatakan bahwa pendidikan saat ini terutama di masa pandemic covid-19 ini memberatkan bagi orang tua, contohnya seperti beliau yang sebagai ibu rumah tangga dimana biasanya tidak pernah mengajarkan anak-anak di rumah. Ketika musim pendemi ini mau tidak mau harus mengajari mereka di rumah. Dan permasalahan beliau anak ada 4 orang, sedangkan yang yang memiliki hp hanya 2. Jadi sedikit menyulitkan untuk anak-anak beliau dalam mengikuti pembelajaran dan masalah yang lain yaitu wifi yang digunakan kadang sangat lelet sehingga membuat anakanak jadi mempersulit keadaan mereka.

Kendala yang lain yaitu dalam hal mengajari anak-anak di rumah terkadang pelajarannya yang lumayan sulit sehingga beliau yang membantu pekerjaan anak-anak dirumah tidak bisa mungkin karena sudah lupa juga pelajaran masa-masa dahulu beliau. Kata beliau bukan hanya orang biasa yang

\footnotetext{
3 Azizy, Melawan Globalisasi: Interpręsi Agama Islam, 121.
} 
mengeluh bahkan ada juga guru yang bercerita mengeluh dengan keadaan seperti ini karena disamping mengajarkan anak orang lain mereka juga harus mengajarkan anak-anak mereka sendiri sehingga pekerjaan itu terbagi dua.

Senada dengan yang dikatakan oleh Ibu RN, Ia mengatakan bahwa pendidikan saat pandemic covid-19 para orang tua mengeluh karena harus mengajari anak-anak mereka dirumah. Dan masalah yang lain bagi orang tua yang tidak berpendidikan sulit untuk mengajari anak-anak mereka berbeda dengan orang tua yang berpendidikan lebih mudah, untuk membantu anak-anak dalam mengajarkan pelajaran. Hanya saja banyak dari orang tua sibuk dengan pekerjaan mereka sehingga menjadikan anak tidak terlalu terawasi dan tidak ada yang membimbing dalam melakukan tugas sekolah mereka.

Kebijakan social distancing maupun physical distancing guna meminimalisir penyebaran COVID-19 mendorong semua elemen pendidikan untuk mengaktifkan kelas meskipun sekolah tutup. Penutupan sekolah menjadi langkah mitigasi paling efektif untuk meminimalisir penyebaran wabah pada anak-anak. Solusi yang diberikan yakni dengan memberlakukan pembelajaran dirumah dengan memanfaatkan berbagai fasilitas penunjang yang mendukung 3 .

Belajar online menuntut peran pendidik mengevaluasi efektivitas dan disesuaikan dengan kebutuhan belajar. Ini penting dilakukan untuk tetap memenuhi aspek pembelajaran seperti proses pengetahuan, moral, keterampilan, kecerdasan dan estetika ${ }^{3}$. Mengingat bahwa perubahan ke pembelajaran online secara tidak langsung berpengaruh pada daya serap peserta

3 Luh Devi Herliandry dkk., "PEిmbelajaran pada masa pandemi covid-19," JTP-Jurnal Teknologi Pendidikan 22, no. 1 (2020): 67.

3 Daxiang Dai dan Gaofeng Lin, 9“Online Home Study Plan for Postponed 2020 Spring Semester During the COVID-19 Epidemic: A Case Study of Tangquan Middle School in Nanjing, Jiangsu Province, China," Jiangsu Province, China (March 15, 2020), 2020. 
$\operatorname{didik}^{4}$. Penting untuk diperhatlkan yakni komunikasi orang tua dan pendidik untuk mewujudkan kemandirian belajar peserta didik selama masa pandemic COVID-19.

Selama masa pandemic COVID-19 pembelajaran dirumah atau online menjadi solusi melanjutkan sisa semester. Pembelajaran online didefinisikan sebagai pengalaman transfer pengetahuan menggunakan video, audio, gambar, komunikasi teks, perangkat lunak ${ }^{4}$ dan dengan dukungan jaringan internet ${ }^{4}$. Ini merupakan modifikasi transfer pengetahuan melalui forum website ${ }^{4}$ dan tren teknologi digital sebagai ciri khas dari revolusi industry 4.0 untuk menunjang pembelajaran selama masa pandemic COVID-19. Integrasi teknologi dan ragam inovasi ciri dari pembelajaran online ${ }^{4}$. Selain itu, yang terpenting adalah kesiapan pendidik dan peserta didik untuk berintereaksi secara online. Namun, tidak semua pendidik, orang tua dan siswa siap dengan adanya pembelajaran daring tersebut, mereka mengalami kesulitan dalam membimbing anak-anak atau siswa mereka.

Ragam manfaat yang diperoleh, tentu memiliki kendala yang dirasakan pendidik maupun peserta didik dalam pembelajaran online. Kendala yang dihadapi yakni kondisi wilayah di Indonesia yang beragam menyebabkan tidak semua wilayah terjangkau oleh layanan internet dan sebaran jaringan internet

\footnotetext{
4 Wahyu Aji Fatma Dewi, "Dampal Covid-19 Terhadap Implementasi Pembelajaran Daring di Sekolah Dasar," Edukatif: Jurnal Ilmu Pendidikan 2, no. 1 (2020): 55-61.

4 G Basilaia dan D Kvavadze, "Transition to Online Education in Schools during a SARS-CoV-2 Coronavirus (COVID-19) Pandemic in Georgia Pedagog,” 2020.

4 Xudong Zhu dan Jing Liu, "Edưcation in and after Covid-19: Immediate responses and long-term visions," Postdigital Science and Education 2, no. 3 (2020): 695-99.

4 Basilaia dan Kvavadze, "Transition to Online Education in Schools during a SARS-CoV-2 Coronavirus (COVID-19) Pandemic in Georgia Pedagog."

4 Maria Dissriany Vista Banggur, Robinson Situmorang, dan Rusmono Rusmono, "Pengembangan Pembelajaran Berbasis Blended Learning Pada Mata Pelajaran Etimologi Multimedia," JTP-Jurnal Teknologi Pendidikan 20, no. 2 (2018): 152-65.
} 
yang lamban sewaktu-waktu ${ }^{4}$. Ini juga memungkinkañ penggunaan internet yang tinggi berpengaruh pada kesehatan peserta didik. Kendala lain yang ditemukan yakni kemampuan orang tua untuk memberikan fasilitas pendidikan online ${ }^{4}$ seperti penggunaan jaringan internet yang membutuhkan biaya ${ }^{4}$.

Sedangkan aspirasi pendidikan di masa pandemic covid-19 ini, menurut masyarakat Desa Jumba yaitu sebagai berikut:

Menurut Ibu MH, Ia menginginkan semoga pendemi ini cepat berakhir dan anak-anak bisa seperti biasa turun ke sekolah untuk menuntut ilmu. Serta untuk masalah pendidikan untuk lebih diperhatikan lagi oleh pemerintah. Adapun Ibu RN mengatakan bahwa anak-anak pun bosan karena belajar di rumah karena tidak bersosialisasi dengan teman-temannya, sehingga membuat mereka suntuk dengan kegiatan belajar dirumah ini. Dan harapan beliau semoga pendemi ini cepat berlalu dan anak-anak kembali beraktivitas di sekolah. Beliau juga mengatakan bahwa anak-anak sekarang kalua bisa tatap muka saja, mereka malas apalagi online semakin menjadi-jadikan mereka malas dalam belajar, apalagi dengan online ini, sehingga mereka lebih sering menggunakan media sosial kalau tidak diawasi mereka bisa menggunakan media sosial ini hal yang tidak penting seperti main game, main tik tok dll.

Secara garis besar bahwa persepsi dan aspirasi pendidikan masyarakat Desa Jumba adalah terbagi menjadi dua bagian, yaitu pendidikan pra globlasisasi (sebelum majunya teknologi) dan pendidikan di era globalisasi (majunya teknologi). Pendidikan di era globalisasi terjadi adanya disrupsi atau perubahan secara besar-besaran yang mengharuskan para guru dan orang tua melek

\footnotetext{
4 Dian Ratu Ayu Uswatun K15asanah, Hascaryo Pramudibyanto, dan Barokah Widuroyekti, "Pendidikan Dalam Masa Pandemi Covid-19," Jurnal Sinestesia 10, no. 1 (2020): 41-48.

4 Thelma Obiakor dan Adedeji Petêr Adeniran, "Covid-19: Impending Situation Threatens to Deepen Nigeria's Education Crisis," 2020.

4 K Jones dan R Sharma, "Reimaginining A Future For Online Learning," 2019.
} 
terhadap teknologi. Hal ini dapat dibuktikan ketika terjadinya pandemic covid19 yang mengharuskan pembelajaran dilakukan secara daring. Namun masyarakat masih belum mampu dan belum siap menghadapi hal tersebut, sehingga mengalami kesulitan.

Kemajuan teknologi yang memang memudahkan manusia dalam segala hal, namun kenyataannya tidak, apalagi dalam dunia pendidikan. Dari segi sarana dan prasarana memanglah mudah, namun dari segi materi yang pada hakikatnya adalah tujuan pendidikan itu tercapai dan terwujud, namun malah terjadi kemrosotan moral, tingkah laku, dan akhlak pada siswa.

Dari uraian di atas dapat digambarkan pada bagan di bawah ini.

\section{PERSEPSI DAN ASPIRASI PENDIDIKAN MASYARAKAT DESA JUMBA}

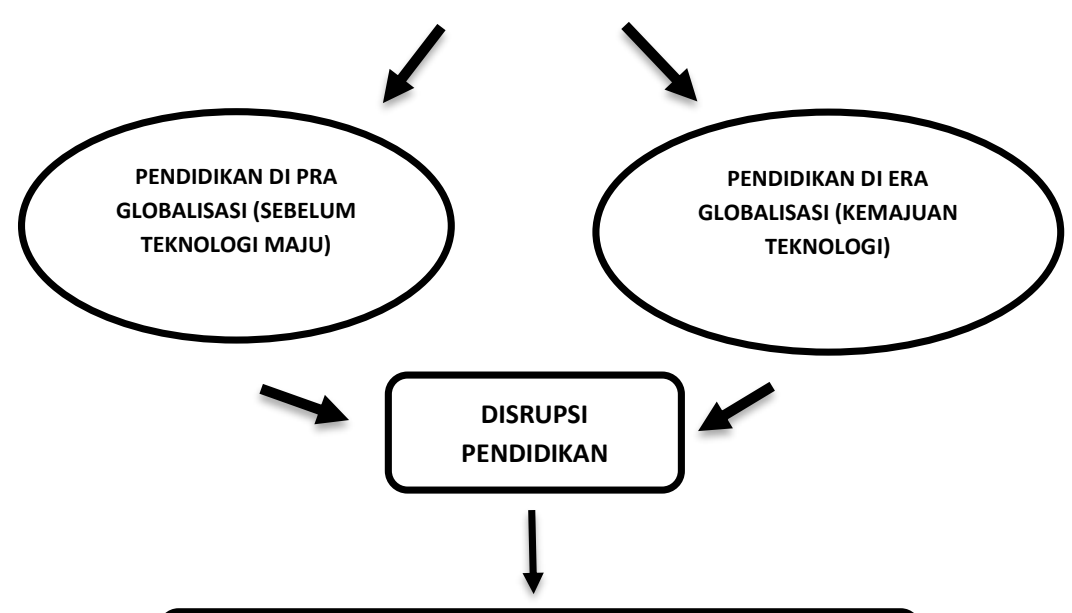

PENDIDIKAN DI MASA PANDEMI COVID-19

\section{SIMPULAN DAN SARAN}


Hasil penelitian ini dapat disimpulkan bahwa terdapat persepsi dan aspirasi pendidikan masyarakat Desa Jumba baik pendidikan era globalisasi dan sebelum era globalisasi. Selain itu juga pendidikan di masa pandemic covid-19. Persepsi dan aspirasi pendidikan masyarakat Desa Jumba yaitu adanya perbedaan antara pendidikan di era globalisasi dan sebelum era globalisasi. Perbedaan tersebut terletak pada akhlak, materi dan sarana dan prasarana. Pendidikan dulu lebih mementingkan akhlak, sedangkan pendidikan sekarang hanya mementingkan investasi. Selain itu materi pendidikan agama yang mengalami perubahan dibanding pendidikan dulu yang lebih kental dan mengedepankan pendidikan agama. Sarana dan prasarana yang memang lebih mudah dan nyaman, namun hal tersebut masih berbeda dengan pendidikan dulu, jika dilihat dari kualitas dan hasil dari pendidikan tersebut. Apalagi pendidikan di masa pandemic covid-19 yang dirasa sangat menyulitkan bagi orang tua, karena dipaksa untuk mengawasi, mengajari dan menggantikan peran guru yang sebagaimana mestinya. Selain itu karena keterbatasan orang tua dalam hal mengawasi anak-anak mereka, karena kesibukan mencari nafkah, keterbatasan kemampuan pengoperasian teknologi. Penelitian ini tentunya masih jauh dari kesempurnaan, oleh karena itu penulis sangat mengharapkan masukan dari para pembaca, agar tulisan ini lebih baik dan lebih sempurna.

\section{DAFTAR RUJUKAN}

Abdullah, Irawan. Kontruksi dan Reproduksi Kebudayaan. Yogyakarta: Pustaka Pelajar, 2010.

Arikunto, Suharsimi. Prosedur Penelitian (Suatu Pendekatan Praktek). Jakarta: Rineka Cipta, 2002.

Azizy, A. Qodri. Melawan Globalisasi: Interpresi Agama Islam. Yogyakarta: Pustaka Pelajar, 2003. 
Azra, Azyumardi. Pendidikan Islam Tradisi dan Modernisasi Menuju Melenium Baru, Logo. Jakarta: Macana Ilmu, 1999.

Bachtiar, Amsal. Filsafat Ilmu. Revisi. Jakarta: Raja Grafindo Persada, 2012.

Bakhri, Amirul. "Tantangan Pendidikan Agama Islam di Madrasah pada Era Globalisasi." Madaniyah 5, no. 1 (2015): 63-86.

Banggur, Maria Dissriany Vista, Robinson Situmorang, dan Rusmono Rusmono. "Pengembangan Pembelajaran Berbasis Blended Learning Pada Mata Pelajaran Etimologi Multimedia." JTP-Jurnal Teknologi Pendidikan 20, no. 2 (2018): 152-65. Basilaia, G, dan D Kvavadze. "Transition to Online Education in Schools during a SARS-CoV-2 Coronavirus (COVID-19) Pandemic in Georgia Pedagog," 2020.

Dacholfany, M Ihsan. "Reformasi Pendidikan Islam Dalam Menghadapi Era Globalisasi." AKADEMIKA: Jurnal Pemikiran Islam 20, no. 1 (2015): 173-94.

Dai, Daxiang, dan Gaofeng Lin. “Online Home Study Plan for Postponed 2020 Spring Semester During the COVID-19 Epidemic: A Case Study of Tangquan Middle School in Nanjing, Jiangsu Province, China." Jiangsu Province, China (March 15, 2020), 2020.

Danim, Sudarman. Agenda Pembaharuan Sistem Pendidikan. Yogyakarta: Pustaka Pelajar, 2003.

Dewi, Eva. "Potret Pendidikan di Era Globalisasi Teknosentrisme dan Proses Dehumanisasi." Sukma: Jurnal Pendidikan 3, no. 1 (2019): 93-116.

Dewi, Wahyu Aji Fatma. "Dampak Covid-19 Terhadap Implementasi Pembelajaran Daring di Sekolah Dasar.” Edukatif: Jurnal Ilmu Pendidikan 2, no. 1 (2020): 5561.

Djamaluddin, dan Aly Abdullah. Kapita Selekta Pendidikan Islam. Bandung: CV Pustaka Setia, 1999.

Dwiningrum, Siti Irene Astuti. Ilmu Sosial \& Budaya Dasar. Yogyakarta: UNY Press, 2012. 
Faisal, Jusuf Amir. Reorientasi Pendidikan Islam. Jakarta: Gema Insani Press, 1995.

Habibah, Syarifah. “Akhlak dan Etika Dalam Islam.” Jurnal Pesona Dasar 1, no. 4 (2015).

Herliandry, Luh Devi, Nurhasanah Nurhasanah, Maria Enjelina Suban, dan Heru Kuswanto. "Pembelajaran pada masa pandemi covid-19." JTP-Jurnal Teknologi Pendidikan 22, no. 1 (2020): 65-70.

Indra, Hasbi. Pendidikan Islam Melawan Globalisasi. Jakarta: Ridamulia, 2005.

Jones, K, dan R Sharma. "Reimagining A Future For Online Learning," 2019.

Khasanah, Dian Ratu Ayu Uswatun, Hascaryo Pramudibyanto, dan Barokah Widuroyekti. "Pendidikan Dalam Masa Pandemi Covid-19.” Jurnal Sinestesia 10, no. 1 (2020): 41-48.

Lexy j. Moleong. Metode Penelitian Kualitatif. Bandung: Remaja Rosdakarya, 2016.

Lubis, M. Solly. Umat Islam Dalam Globalisasi. Jakarta: Gema Insani Press, 1997.

Machali, Imam. Pendidikan Islam dan Tantangan Globalisasi. Yogyakarta: PRESMA Fak. Tarbiyah UIN Sunan Kalijaga, 2004.

Mulyasa, Dedi. Kurikulum Tingkat Satuan Pendidikan. Bandung: Rosda, 2007.

Obiakor, Thelma, dan Adedeji Peter Adeniran. "Covid-19: Impending Situation Threatens to Deepen Nigeria's Education Crisis," 2020.

Roqib, Moh. Pendidikan Perempuan. Yogyakarta: Gema Media dengan STAIN Press, 2003.

Rusniati, Rusniati. "Pendidikan Nasional Dan Tantangan Globalisasi: Kajian Kritis Terhadap Pemikiran A. Malik Fajar.” JURNAL ILMLAH DID AKTIKA: Media Ilmiah Pendidikan dan Pengajaran 16, no. 1 (2015): 105-28.

Said, Muhammad, dan Juminar Affan. Mendidik dari Zaman Ke Zaman. Jakarta: Kalam Mulia, 1987.

Selwyn, N. "Education and Technology. Key Issues and Debates. London: Continuum Int. Publ.” Group, 2011. 
Taopan, Yana F, Mintje Ratoe Oedjoe, dan Andy Nabu Sogen. "Dampak Perkembangan Teknologi Informasi dan Komunikasi Terhadap Perilaku Moral Remaja di SMA Negeri 3 Kota Kupang." Jurnal Kependidikan: Jurnal Hasil Penelitian dan Kajian Kepustakaan di Bidang Pendidikan, Pengajaran dan Pembelajaran 5, no. 1 (2019): 61-74.

Tim Penyusun. Pengantar Studi Islam. Surabaya: IAIN Sunan Ampel Press, 2009.

Usa, Muslim. Pendidikan Islam di Indonesia antara Cita dan Fakta. Yogyakarta: Tiara Wacana, 1991.

Yamin, Moh. Menggugat Pendidikan Indonesia. Yogyakarta: Ar-Ruzz Media, 2009.

Zhu, Xudong, dan Jing Liu. "Education in and after Covid-19: Immediate responses and long-term visions." Postdigital Science and Education 2, no. 3 (2020): 695-99. 